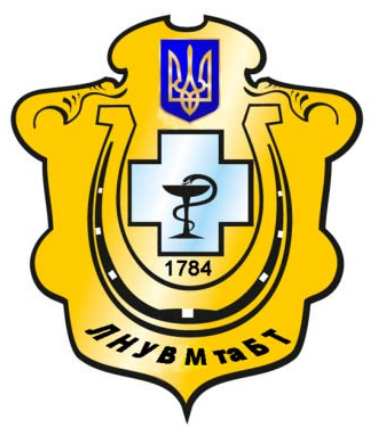

Науковий вісник Львівського національного університету ветеринарної медицини та біотехнологій імені С.3. Гжицького

Scientific Messenger of Lviv National University of Veterinary Medicine and Biotechnologies named after S.Z. Gzhytskyj

doi:10.15421/nvlvet6823

ISSN 2413-5550 print

ISSN 2518-1327 online

$\underline{\text { http://nvlvet.com.ua/ }}$

УДК 637.5.04/.07: 637.52: 613.281

\title{
Визначення амінокислотного складу та мікробіологічних показників варених ковбас
}

\author{
О.П. Фурсік, І.М. Страшинський, В.М. Пасічний \\ oksana.fursik@mail.ru
}

Національний університет харчових технологій, вул. Володимирська, 68, м. Київ, 01601, Україна

\begin{abstract}
Аналіз структури харчування різних груп населення свідчить, щео в даний час потреби в білках, в першу чергу тваринного походження, задовольняються лише на $80 \%$.

Для досліджень розробили рецептури варених ковбас із заміною частини м'ясної сировини гідратованою білоквмісною харчовою композичією (до 30\%) та м'ясом птиці механічного обвалювання (до 30\%). Для доведення доцільності використання розробленої композиції у складі варених ковбасних виробів провели визначення амінокислотного складу та вивчили ї̈ вплив на термін зберігання готових ковбас шляхом дослідження мікробіологічних показників. Доведено, шьо спрямоване застосування харчових композицій у технології варених ковбас дозволяс нормалізувати загальний хімічний $і$ амінокислотний склад, забезпечуючи мікробіологічну стабільність готової продукиії. Встановлено, щяо заміна м'ясної сировини ФХК в кількості 30\% (характерна для дослідного зразка №1) дозволяє зберегти амінокислотний склад продукту, а додаткове внесення МПМО (характерне для дослідного зразка №2) призводять до його зменшення, особливо таких незамінних амінокислот як ізолейцин та валін. Розроблені композииї сприяють зниженню залишкової мікрофлори та пригнічують зростання мезофільно-аеробних і факультативно анаеробних мікроорганізмів в готових виробах, щзо пов'язано з їх нижчим початковим мікробіологічним обсіменінням порівняно із м'ясною сировиною.
\end{abstract}

Ключові слова: білоквмісна харчова композиція, варена ковбаса, амінокислотний склад, мікробіологічні показники, м'ясо птиці механічного обвалювання.

\section{Определение аминокислотного состава и микробиологических показателей вареных колбас}

\author{
О.П. Фурсик, И.М. Страшинский, В.Н. Пасичный \\ oksana.fursik@mail.ru
}

Национальный университет пищеевых технологий, ул. Владимирская, 68, г. Киев, 01601, Украина

\begin{abstract}
Анализ структуры питания различных групп населения свидетельствует, что в настоящее время потребности в белках, в первую очередь животного происхождения, удовлетворяются лишь на $80 \%$.

Для исследований разработали рецептуры вареных колбас с заменой части мясного сырья гидратированной содержашей белок пищевой композичией (до 30\%) и мясом птицы механической обвалки (до 30\%).

Для доказательства цуелесообразности использования разработанной композиции в составе колбас провели определение аминокислотного состава и изучили ее влияние на срок хранения готовых колбас путем исследования микробиологических показателей.

Доказано, что направленное применение пищевых композиций в технологии вареных колбас позволяет нормализовать общий химический и аминокислотный состав, обеспечивая микробиологическую стабильность готовой продукиии.

Ключевые слова: содержащая белок пищевая композищия, вареная колбаса, аминокислотный состав, микробиологические показатели, мясо птицьы механической обвалки.
\end{abstract}

\section{Citation:}

Fursik O., Strashynskiy I., Pasichniy V. (2016). Definitions amino acid composition and microbiological indicators of cooked sausages. Scientific Messenger LNUVMBT named after S.Z. Gzhytskyj, 18, 2(68), 115-120. 


\title{
Definitions amino acid composition and microbiological indicators of cooked sausages
}

\author{
O. Fursik, I. Strashynskiy, V. Pasichniy \\ oksana.fursik@mail.ru \\ National University of Food Technologies, \\ Volodymyrska Str., 68, Kyiv, 01601, Ukraine
}

\begin{abstract}
Protein has an important place in the nutrition of the population and ensures the supply of the human body useful and essential components of food. The meat industry provides needs of the population in food products, which are the main source of complete protein food.

Analysis of the nutrition structure in of various population groups demonstrates that currently needs to proteins, primarily of animal origin, is satisfied by only $80 \%$. The objective of the article is to study and experimental evidence of the appropriateness of applying the protein-containing food composition in the technology of cooked sausages.

For this purpose in technology of cooked sausages technology was used developed and studied composition. It includes: a protein pork skin-Belkoton-S95, soy isolate, xanthan gum, guar gum and carboxymethylcellulose.

For the studies was developed recipe of cooked sausage with replacing part of meat raw material hydrated protein-containing food composition (30\%), and mechanically deboned poultry meat (30\%).

To prove the feasibility of using the developed compositions as part of the sausages had a determination of amino acid composition and studied its effect on the shelf life of ready sausages by examining microbiological parameters.

It has been established that the replacement of raw meat for protein-containing food composition in an amount of 30\% (prototype №1) saves the amino acid composition of the product. The additional introduction of mechanically deboned poultry meat (prototype №2) reduces the essential amino acids such as isoleucine and valine.

The developed composition was helping to reduce the residual microflora and inhibiting the growth of mesophilic aerobic and facultative-anaerobic microorganisms in the finished product. This is related to their low initial microbiological colonization compared with the raw meat. It is proved that the directed use of food compositions in technology of cooked sausages helps to normalize the total chemical and amino acid composition, providing microbiological stability of the finished product.
\end{abstract}

Key words: food composition containing protein, cooked sausage, amino acid composition, microbiological parameters, mechanically deboned poultry meat.

\section{Вступ}

Білок займає важливе місце у харчуванні населення і забезпечує надходження в організм людини корисних і незамінних компонентів їжі. Задоволення потреб населення у харчових продуктах, які є основними джерелами повноцінного білкового харчування, здійснює м'ясна промисловість.

Аналіз структури харчування різних груп населення свідчить, що в даний час споживання харчових продуктів не тільки повністю забезпечує, але у значної частини населення перевищує енергетичні потреби. У той же час потреби в білках, в першу чергу тваринного походження, задовольняються лише на 80\% (Lisitsyin et al., 2006).

Проблема збільшення ресурсів харчового білка раніше вирішувалась за рахунок інтенсифікації виробництва продукції тваринництва. Зараз при переробці тваринної сировини велика увага надається більш повному використанню білків молочних продуктів і вторинній продукції м'ясної промисловості (крові, кісток, субпродуктів, сполучної тканини і т. ін.) на харчові цілі (Potipaeva et al., 2008).

В той же час великим резервом у вирішенні проблеми білка, збільшенні об'ємів виробництва збалансованих за амінокислотним складом білкових продуктів, у тому числі м'ясних, є рослинна сировина. Розробка нових продуктів харчування із застосуванням рослинного білка із зернобобової сировини є актуальною.

Проте більшість рослинних білків і частина тваринних $є$ неповноцінними. В зв'язку з цим застосу- вання білкових препаратів із вторинної сировини в технології ковбасного виробництва пов'язане 3 вирішенням завдання отримання готового продукту із заданими якісними характеристиками (хімічний склад, ступінь збалансованості харчових речовин, рівень біологічної цінності, комплекс органолептичних показників). Тому білкові препарати доцільно використовувати у складі бінарних і багатокомпонентних сумішей в певних співвідношеннях компонентів, що забезпечують або взаємозбагачення за амінокислотним складом, або модифікацію функціональнотехнологічних властивостей (ФТВ) (Semenova, 2009).

Сучасні тенденції в області удосконалення структури харчування спрямовані на створення асортименту доступної м'ясної продукції із високим вмістом білків 3 використанням комплексних добавок для стабілізації якості.

Виробництво комбінованих м'ясних виробів, до складу яких входять білкові добавки рослинного (соя, горох, сочевиця) та тваринного походження дозволяє раціонально використовувати сировину, запобігти дефіциту повноцінних білків у харчуванні, підвищити харчову й біологічну цінність продукції (Iltyakov et al., 2006).

Використання суміші гідроколоїдів та білкових препаратів тваринного та рослинного походження, які володіють синергічними властивостями, дозволяє підсилити їх властивості, що сприятиме покращенню ФТВ та структурно-механічних властивостей (СМВ) i дозволить взаємозбагатити суміш білком та збалансувати за амінокислотним складом. 
Schnackel W. та ін. в фаршах для ковбас типу Франкфуртської замінювали частину м'ясної сировини $(10-20 \%)$ комбінованим білковим препаратом, що представляє собою суміш білкового концентрату зі знежиреної сироватки 76,5\%, свинячої крові $14,2 \%$ і вареної гомогенізованої свинячої шкурки 9,3\%. Встановлено, що заміна $10-45 \%$ м'ясної сировини комбінованим білковим продуктом дозволяє підвищити харчову цінність і засвоюваність ковбас. За основними органолептичними показниками якість ковбаси 3 додаванням $10-45 \%$ комбінованого білкового продукту практично не відрізнялася від контрольних зразків, маючи при цьому кращі показники кольору на poзpizi.

У м'ясних січених виробах, виготовлених на основі яловичого фаршу з білковим наповнювачем (БН), спостерігаються незначні зміни хімічного складу, які виражаються в підвищенні частки загальної вологи і незначному зниженні масової частки білка, жиру та зольних елементів. В цілому, за вмістом основних нутрієнтів отримані зразки виробів наближені до контрольних. Встановлено, що в дослідних зразках відсутні лімітуючі амінокислоти, показники коефіцієнта різниці амінокислотного скору (КРАС) і коефіцієнта утилітарності вказують на поліпшення збалансованості незамінних амінокислот (Moskalenko and Kovalenko, 2008).

Мета роботи - обгрунтування і експериментальне доведення доцільності застосування білоквмісної харчової композиції у технології варених ковбас та дослідження амінокислотного складу і мікробіологічних показників.

\section{Матеріал і методи досліджень}

Об'єкт дослідження - технологія варених ковбас із використання білоквмісної функціональної харчової композиції (ФХК).

Предмет дослідження - варені ковбаси із використанням м'яса птиці механічного обвалювання (МПМО) та заміною частини м'ясної сировини розробленою харчовою композицією.

Досвід роботи підприємств м'ясопереробної галузі України та сучасний підхід до вирішення технологічних і економічних завдань свідчить про доцільність комплексного використання білкових препаратів 3 різноманітними стабілізаторами та емульгаторами. Це дозволяє, з одного боку, знизити вартість продукції, що випускається, а з іншого - покращити ФТВ, СМВ та органолептичні показники. Для цього у технології варених ковбас використали розроблену і досліджену ФХК зі співвідношенням компонентів наведених в рецептурі №3 (до її складу входять: білок свинячої шкурки - Белкотон-С95, соєвий ізолят, камеді гуару та ксантану, а також карбоксиметилцелюлоза) (Pasichnyi et al., 2015).

За контроль обрано рецептуру варених ковбас до складу якої входить: яловичина другого сорту, свинина напівжирна, м'ясо птиці (червоне куряче м'ясо), шпик (грудний), борошно, меланж, сіль та спеції. На іï основі розробили рецептури дослідних зразків варених ковбас, в яких провели заміну м'ясної сировини відповідною кількістю гідратованої ФХК (30\%) та МПМО (30\%). Гідратацію композиції проводили водою $\left(\mathrm{t}=8-12{ }^{\circ} \mathrm{C}\right)$ з наступним перемішування і вносили на стадії кутерування 3 необхідною кількістю кухонної солі. Додатково вносилась волога у кількості $20 \%$ до основної сировини.

Виготовлення зразків проводили згідно стандартної технології варених ковбас, $з$ додаванням гідратованої ФХК на етапі складання фаршу після внесення нежирної сировини, фосфатів та нітриту натрію.

Дослідним шляхом встановлено, що для отримання якісних ковбасних виробів з використанням 30\% МПМО частка гідратованої білоквмісної композиції не повинна перевищувати $30 \%$, що забезпечує високі показники ФТВ та СMB (Strashynskyi et al., 2015; Strashynskyi et al., 2016).

Для контрольного зразка та обраних дослідних зразків визначили амінокислотний склад білків методом іонообмінної рідинно-колончатої хроматографії (Ovchinnikova, 1974) та мікробіологічні показники.

Розрахунковим методом визначили індекс біологічної цінності або амінокислотний СКОР (відношення скору білка продукту до скору білка еталону). Розрахунок біологічної цінності варених ковбас здійснювали за формулою М.П. Чернікова (Ovchinnikova, 1974).

Рівняння розрахунку біологічної цінності

$$
\text { БЦ }=100-\mathrm{KРAC,} \mathrm{\%} \mathrm{.}
$$

де, КРАС - це різниця амінокислотного скору незамінних амінокислот і скору амінокислоти, що лімітує.

\section{Результати та їх обговорення}

Біологічна цінність, як критерій оцінки білка, має велике значення для визначення ефективності його використання організмом людини. Амінокислотний склад продукту є одним з показників його біологічної цінності.

Для визначення зміни амінокислотного складу в залежності від рівня заміни м'ясної сировини на ФХК був проведений амінокислотний аналіз контрольного та дослідних зразків варених ковбас. Результати досліджень наведено в таблиці 1.

Згідно даних у контрольному зразку варених ковбас СКОР незамінних амінокислот становив: валін $69 \%$, ізолейцин $-70 \%$, лейцин $-114 \%$, тирозин і фенілаланін - $118 \%$, лізин - 150\%, треонін - $124 \%$, цистин і метіонін - 110\%. Лімітованою амінокислотою в даному випадку являється валін.

У дослідному зразку №1 міститься наступна кількість незамінних амінокислот: валін - 62\%, ізолейцин - 68\%, лейцин - $111 \%$, тирозин і фенілаланін - 126\%, лізин - 141\%, треонін - 122\%, цистин і метіонін $106 \%$. Лімітованою амінокислотою в даному випадку являється валін. 
Амінокислотний аналіз продукту, мг білка на 100 г

\begin{tabular}{|c|c|c|c|c|c|c|c|}
\hline \multirow[t]{2}{*}{ Амінокислоти } & \multirow{2}{*}{$\begin{array}{c}\text { Вміст незамінних амі- } \\
\text { нокислот в } 1 \text { г харчово- } \\
\text { го білка (в \% по мг) }\end{array}$} & \multicolumn{2}{|c|}{ Контрольний зразок } & \multicolumn{2}{|c|}{$\begin{array}{l}\text { Дослідний зразок } \\
\text { №1 (30 \% ФХК) }\end{array}$} & \multicolumn{2}{|c|}{$\begin{array}{c}\text { Дослідний зразок } \\
\text { №2 (30\% ФХК + } \\
\text { 30\% МПМО) } \\
\end{array}$} \\
\hline & & $\begin{array}{c}\text { Кіль-кість } \\
\text { в мг. }\end{array}$ & \% по мг & $\begin{array}{l}\text { Кіль-кість } \\
\text { в мг. }\end{array}$ & $\%$ по мг & $\begin{array}{c}\text { Кіль-кість } \\
\text { в мг. }\end{array}$ & \% по мг \\
\hline Лізин & 5,5 & 1,069 & 8,24 & 0,892 & 7,74 & 1,258 & 12,88 \\
\hline Гістидин & & 0,375 & 2,89 & 0,395 & 3,43 & 0,584 & 5,98 \\
\hline Аргінін & & 0,778 & 6,00 & 0,707 & 6,14 & 0,690 & 7,06 \\
\hline Аспарагінова кислота & & 1,359 & 10,48 & 1,278 & 11,10 & 1,401 & 14,33 \\
\hline Треонін & 4,0 & 0,644 & 4,97 & 0,562 & 4,88 & 0,510 & 5,22 \\
\hline Серин & & 0,702 & 5,41 & 0,626 & 5,44 & 0,290 & 2,97 \\
\hline Глут. кислота & & 2,499 & 19,27 & 2,264 & 19,66 & 2,187 & 22,38 \\
\hline Пролін & & 0,575 & 4,43 & 0,506 & 4,40 & 0,117 & 1,20 \\
\hline Гліцин & & 0,769 & 5,93 & 0,640 & 5,56 & 0,954 & 9,77 \\
\hline Аланін & & 0,935 & 7,21 & 0,777 & 6,75 & 0,271 & 2,78 \\
\hline Валін & 5,0 & 0,448 & 3,46 & 0,357 & 3,10 & 0,158 & 1,61 \\
\hline Цистин & \multirow{2}{*}{3,5} & 0,140 & 1,08 & 0,112 & 0,97 & 0,216 & 2,21 \\
\hline Метіонін & & 0,360 & 2,77 & 0,316 & 2,75 & 0,143 & 1,46 \\
\hline Ізолейцин & 4,0 & 0,364 & 2,81 & 0,312 & 2,71 & 0,069 & 0,70 \\
\hline Лейцин & 7,0 & 1,033 & 7,97 & 0,897 & 7,79 & 0,247 & 2,53 \\
\hline Тирозин & \multirow{2}{*}{6,0} & 0,438 & 3,38 & 0,413 & 3,59 & 0,239 & 2,45 \\
\hline Фенілаланін & & 0,481 & 3,71 & 0,459 & 3,99 & 0,436 & 4,47 \\
\hline Сума & & 12,97 & 100,0 & 11,512 & 100,0 & 9,771 & 100,0 \\
\hline
\end{tabular}

Порівнявши отримані дані із контрольним зразком можна відзначити збільшення кількості тиросину на $8 \%$ та незначне зменшення кількості таких амінокислот як лізин на 9\%, треонін на 2\%, цистин на $4 \%$, лейцин на 3\%. Проте показники їх СКОРу перевищують $100 \%$, тоді як для валіну та ізолейцину цей показник зменшився на $7 \%$ та 2\% відповідно і складає менше $100 \%$.

У дослідному зразку №2 лімітованою амінокислотою є ізолейцин СКОР якої складає 18\%, що менше на
$52 \%$ порівняно 3 контролем та на 50\% порівняно 3 дослідним зразком №1. Також в дефіциті знаходяться такі незамінні амінокислоти як валін (32\%) та лейцин (36\%). Для інших амінокислот СКОР знаходиться на високому рівні.

Щоб оцінити харчову адекватність білкових компонентів нової продукції щодо ступеня іiї засвоюваності, розраховані показники та критерії біологічної цінності білка. Дані наведені в таблиці 2.

Показники біологічної цінності білків

Таблиияя 2

\begin{tabular}{|c|c|c|c|}
\hline Показник & $\begin{array}{c}\text { Контрольний } \\
\text { зразок }\end{array}$ & $\begin{array}{c}\text { Дослідний зразок } \\
\text { №1 }\end{array}$ & $\begin{array}{c}\text { Дослідний зразок } \\
\text { №2 }\end{array}$ \\
\hline $\begin{array}{c}\text { Коефіцієнт різниці амінокислотного скору незамінних і } \\
\text { лімітованої амінокислот (КРАС), \% }\end{array}$ & 38,7 & 43,1 & 77,7 \\
\hline Біологічна цінність (БЦ), $\%$ & 61,3 & 56,9 & 22,3 \\
\hline
\end{tabular}

Заміна розробленою білоквмісною ФХК у рецептурах варених ковбас м'ясної сировини суттєво не впливає на амінокислотний склад (спостерігається незначне збільшення вмісту тиросину та зменшення інших незамінних амінокислот). При замінні м'ясної сировини, що входить до контрольної рецептури ФХК та МПМО помітно зменшується кількість таких незамінних амінокислот як ізолейцин (СКОР 18 - 22\%), лейцин (СКОР 36 - 70\%) та валін (СКОР $32-36 \%$ ). Поряд 3 цим значно збільшується вміст лізину до 233 $-234 \%$.

В технології м'яса і м'ясопродуктів одним з важливих показників $є$ мікробіологічна стабільність і санітарно-гігієнічна безпечність сировини і готової продукції.

Розвиток мікроорганізмів, зокрема гнилісної мікрофлори, супроводжується розпадом білків, поліпептидів, амінокислот, в тому числі і незамінних, що каталізується ферментними системами мікроорганізмів, значно знижує біологічну цінність продукту, погіршує, колір запах, консистенцію, призводить до утворення шкідливих для організму людини речовин.

Інтенсивність і характер розвитку мікробіологічних процесів залежить від складу і властивостей продуктів, їх початкового мікробіологічного обсіменіння i таких зовнішніх факторів, як температура, відносна вологість, склад атмосфери, тривалість зберігання, а також вмісту вологи, активності води, величини $\mathrm{pH}$.

Для оцінки якості харчових продуктів і особливо м'ясних дуже важливим $є$ встановлення їх мікробіологічних показників. Як відомо, перелік груп мікроорганізмів, що підлягають нормуванню в тих або інших продуктах, визначають, виходячи $з$ їх рецептурного і хімічного складу, технології виготовлення, умов і термінів зберігання. 
Мікробіологічні показники варених ковбас

\begin{tabular}{|c|c|c|c|c|c|c|}
\hline \multirow{4}{*}{ 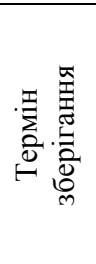 } & \multirow{4}{*}{ Зразок } & \multicolumn{5}{|c|}{ Показник } \\
\hline & & $\begin{array}{c}\text { МАФАМ КУО в } \\
1 \Gamma\end{array}$ & $\begin{array}{c}\text { Salmonella, в } \\
25 \Gamma\end{array}$ & $\begin{array}{c}\text { Сульфіт- } \\
\text { редукуючі клос- } \\
\text { тридії в } 0,1 \text { г }\end{array}$ & БГКП в 1 г & $\begin{array}{c}\text { Staphy- } \\
\text { lococus aure- } \\
\text { us, в } 1 \text { г } \\
\end{array}$ \\
\hline & & \multicolumn{5}{|c|}{ Норма } \\
\hline & & $\begin{array}{c}\text { не більше } 1 \cdot 10^{3} \\
\text { КУО/г }\end{array}$ & не допуск. & не допуск & не допуск & не допуск \\
\hline \multirow{3}{*}{ Фон } & Контрольний зразок & $3,5 \cdot 10^{2}$ & \multicolumn{4}{|c|}{ не виявлено } \\
\hline & $\begin{array}{c}\text { Дослідний зразок } \\
\text { №1 }\end{array}$ & $2,2 \cdot 10^{2}$ & \multicolumn{4}{|c|}{ не виявлено } \\
\hline & $\begin{array}{c}\text { Дослідний зразок } \\
\text { №2 }\end{array}$ & $3,0 \cdot 10^{2}$ & \multicolumn{4}{|c|}{ не виявлено } \\
\hline \multirow{3}{*}{10 діб } & Контрольний зразок & $9,5 \cdot 10^{2}$ & \multicolumn{4}{|c|}{ не виявлено } \\
\hline & $\begin{array}{c}\text { Дослідний зразок } \\
\text { №1 }\end{array}$ & $3,0 \cdot 10^{2}$ & \multicolumn{4}{|c|}{ не виявлено } \\
\hline & $\begin{array}{c}\text { Дослідний зразок } \\
\text { №2 }\end{array}$ & $5 \cdot 10^{2}$ & \multicolumn{4}{|c|}{ не виявлено } \\
\hline \multirow{3}{*}{13 діб } & Контрольний зразок & $16 \cdot 10^{2}$ & \multicolumn{4}{|c|}{ не виявлено } \\
\hline & $\begin{array}{c}\text { Дослідний зразок } \\
\text { №1 }\end{array}$ & $4,5 \cdot 10^{2}$ & \multicolumn{4}{|c|}{ не виявлено } \\
\hline & $\begin{array}{c}\text { Дослідний зразок } \\
\text { №2 }\end{array}$ & $9 \cdot 10^{2}$ & \multicolumn{4}{|c|}{ не виявлено } \\
\hline
\end{tabular}

Мікробіологічні показники є невід'ємною складовою частиною комплексної оцінки якості і безпеки продуктів харчування.

Для перевірки відповідності мікробіологічних показників варених ковбас вимогам стандарту всі дослідні і контрольні зразки продукції були досліджені відповідно до стандартних методик і представлені в таблиці 3.

Як видно з даних, представлених в таблиці 3, вміст мікроорганізмів всіх груп, що нормуються, на 10 день від зберігання не перевищує допустимих рівнів. Також у дослідних зразках на початку зберігання та на 13 день показник МАФАМ менший у порівнянні 3 контрольним зразком та не перевищує норми (на відміну від контрольного зразка на 13 день зберігання). Це свідчить про кращу мікробіологічну стабільність варених ковбас із заміною м'ясної сировини білоквмісною ФХК, що пояснюється меншим мікробним обсіменінням створеної композиції порівняно з м'ясною сировиною. Дослідні зразки підтвердили безпечність і якість готового продукту та відповідність показникам нормативних документів.

\section{Висновки}

Встановлено, що заміна м'ясної сировини ФХК в кількості 30\% (характерна для дослідного зразка №1) дозволяє зберегти амінокислотний склад продукту, а додаткове внесення МПМО (характерне для дослідного зразка № 2) призводять до його зменшення, особливо таких незамінних амінокислот як ізолейцин та валін.

Розроблені композиції сприяють зниженню залишкової мікрофлори та пригнічують зростання мезофільно-аеробних і факультативно анаеробних мікроорганізмів в готових виробах, що пов'язано з їх нижчим початковим мікробіологічним обсіменінням порівняно із м'ясною сировиною.
Таким чином, спрямоване застосування харчових композицій у технології варених ковбас дозволяє нормалізувати загальний хімічний і амінокислотний склад, компенсувати відхилення функціональнотехнологічних властивостей основної сировини, залучити у виробництво харчових продуктів білоквмісної сировини і вивільнити частину високоякісної м'ясної сировини, поліпшити якісні характеристики, забезпечуючи мікробіологічну стабільність, та знизити собівартість готової продукції.

Перспективи подальших досліджень. Незважаючи на високі ФТВ та економічну доцільність амінокислотний склад у дослідному зразку №2 погіршується, що свідчить про необхідність подальших досліджень для коригування складу варених ковбас з метою створення якісної, економічно доступної та збалансованої за амінокислотним складом продукції.

\section{Бібліографічні посилання}

Lisitsyin, A.B., Chernuha, I.M., Semenova, A.A., Aleksahina, V.A. (2006). Osnovnyie printsipyi sovershenstvovaniya assortimenta i stabilizatsii kachestva kolbasnyih izdeliy. Vse o myase. 1, 4-7 (in Russian).

Potipaeva, N.N., Gurinovich, G.V., Patrakova, I.S., Patshina, M.V. (2008). Pischevyie dobavki i belkovyie preparatyi dlya myasnoy promyishlennosti: uchebnoe posobie. Kemerovo. 101-158 (in Russian).

Semenova, A.A. (2009). O tehnologicheskoy praktike primeneniya pischevyih dobavok $\mathrm{v}$ myasnoy promyishlennosti. Vse o myase. 1, 17-24 (in Russian).

Iltyakov, A.V., Miklyashevski, P., Pryanishnikov, V.V., Babicheva, E.V. (2006). Ispolzovanie soevyih belkov $\mathrm{v}$ pererabotke myasa. VsYo o myase. 3, 10-13 (in Russian).

Moskalenko, O.V., Kovalenko, S.M. (2008). Vyrobnytstvo miasnykh sichenykh vyrobiv na osnovi 
yalovychoho farshu $\mathrm{z}$ napivfabrykatom bilkovym (NB). Naukovi zdobutky molodi - vyrishenniu problem kharchuvannia liudstva $\mathrm{u}$ KhKhI stolitti: prohr. i mater. 74-oi nauk. konf. molodykh vchenykh, aspirantiv i studentiv. K., 200 (in Ukrainian).

Pasichnyi, V.M., Strashynskyi, I.M., Fursik, O.P. (2015). Doslidzhennia emulsii na osnovi bilokvmisnykh funktsionalnykh kharchovykh kompozytsii. Tekhnolohichnyi audyt ta rezervy vyrobnytstva. 3/3(23), 51-55 (in Ukrainian).

Strashynskyi, I.M., Pasichnyi, V.M., Dubkovetskyi, I.V., Fursik, O.P. (2015). Doslidzhennia vlastyvostei hotovykh vyrobiv $\mathrm{z}$ vykorystanniam funktsionalnoi kharchovoi kompozytsii». Naukovyi visnyk LNUVMBT imeni S.Z. Hzhytskoho. 17, 4(64), 136141 (in Ukrainian).

Strashynskyi, I.M., Pasichnyi, V.M., Fursik, O.P. (2016). Stabilizatsiia pokaznykiv farshiv varenykh kovbas $\mathrm{z}$ vykorystanniam bilokvmisnoi kompozytsii. Naukovi pratsi NUKhT. 1(22), 210-218 (in Ukrainian).

Ovchinnikova, Yu.A. (1974). Novyie metodyi analiza aminokislot, peptidov i belkov. Moskva: Mir. (in Russian).

Стаття надійшла до редакиії 26.09.2016 